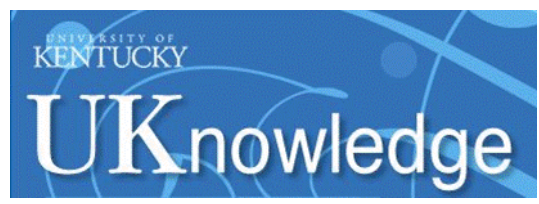

University of Kentucky

UKnowledge

\title{
Chemical and Statistical Analysis of a Sampled Interval in the Camp Nelson Limestone (Upper Ordovician) Madison County, Central Kentucky
}

\author{
Garland R. Dever Jr. \\ University of Kentucky \\ Warren $\mathrm{H}$. Anderson \\ University of Kentucky, wanderson@uky.edu \\ Henry E. Francis \\ University of Kentucky \\ O. Barton Davidson \\ University of Kentucky, bdavidson@uky.edu \\ Mark F. Thompson \\ University of Kentucky \\ Follow this and additional works at: https://uknowledge.uky.edu/kgs_ic \\ Part of the Geology Commons
}

Right click to open a feedback form in a new tab to let us know how this document benefits you.

\section{Repository Citation}

Dever, Garland R. Jr.; Anderson, Warren H.; Francis, Henry E.; Davidson, O. Barton; and Thompson, Mark F., "Chemical and Statistical Analysis of a Sampled Interval in the Camp Nelson Limestone (Upper Ordovician) Madison County, Central Kentucky" (1994). Kentucky Geological Survey Information Circular. 55.

https://uknowledge.uky.edu/kgs_ic/55

This Report is brought to you for free and open access by the Kentucky Geological Survey at UKnowledge. It has been accepted for inclusion in Kentucky Geological Survey Information Circular by an authorized administrator of UKnowledge. For more information, please contact UKnowledge@lsv.uky.edu. 


\section{Chemical and Statistical Analysis \\ of a Sampled Interval \\ in the Camp Nelson Limestone \\ (Upper Ordovician) \\ Madison County, Central Kentucky}

Garland R. Dever, Jr., Warren H. Anderson, Henry E. Francis, O. Barton Davidson, and Mark F. Thompson

Kentucky Geological Survey

With a section on:

Statistical Analysis of Limestone Sampling Procedure

Richard J. Kryscio and Diane Davis

University of Kentucky

Biostatistics Consulting Unit

INFORMATION CIRCULAR 51

Series XI, 1994

https://doi.org/10.13023/kgs.ic51.11 
KENTUCKY GEOLOGICAL SURVEY

Donald C. Haney, State Geologist and Director

UNIVERSITY OF KENTUCKY, LEXINGTON

\section{CHEMICAL AND STATISTICAL ANALYSIS \\ OF A SAMPLED INTERVAL \\ IN THE CAMP NELSON LIMESTONE \\ (UPPER ORDOVICIAN),}

MADISON COUNTY, CENTRAL KENTUCKY

Garland R. Dever, Jr., Warren H. Anderson, Henry E. Francis, O. Barton Davidson, and Mark F. Thompson

Kentucky Geological Survey

With a Section on

STATISTICAL ANALYSIS

OF LIMESTONE SAMPLING PROCEDURE

Richard J. Kryscio and Diane Davis

University of Kentucky

Biostatistics Consulting Unit 
UNIVERSITY OF KENTUCKY

Charles T. Wethington, Jr., President

Delwood C. Collins, Acting Vice President for Research and Graduate Studies

Jack Supplee, Director, Fiscal Affairs and Sponsored Project Administration

\section{KENTUCKY GEOLOGICAL SURVEY ADVISORY BOARD}

Hugh B. Gabbard, Chairman, Richmond

Steve Cawood, Pineville

Larry R. Finley, Henderson

Kenneth Gibson, Madisonville

Wallace W. Hagan, Lexington

Phil M. Miles, Lexington

W. A. Mossbarger, Lexington

Henry A. Spalding, Hazard

Jacqueline Swigart, Louisville

Ralph N. Thomas, Owensboro

George H. Warren, Jr., Owensboro

David A. Zegeer, Lexington

\section{KENTUCKY GEOLOGICAL SURVEY}

Donald C. Haney, State Geologist and Director

John D. Kiefer, Assistant State Geologist for Administration

James C. Cobb, Assistant State Geologist for Research

\section{ADMINISTRATIVE DIVISION}

Personnel and Finance Section:

James L. Hamilton, Administrative Staff Officer II

Roger S. Banks, Account Clerk V

Clerical Section:

Jody L. Fox, Staff Assistant VII

Joyce Belcher, Staff Assistant VI

Juanita G. Smith, Staff Assistant V, Henderson Office

\section{Publications Section:}

Donald W. Hutcheson, Head

Margaret Luther Smath, Geologic Editor III

Terry D. Hounshell, Chief Cartographic Illustrator

Richard A. Smath, Geologist III, ESIC Coordinator

Michael L. Murphy, Principal Drafting Technician

Gwenda K. Rulo, Drafting Technician

William A. Briscoe, III, Publication Sales Supervisor

Shirley D. Dawson, Staff Assistant V

\section{Geologic Data Center:}

O. Barton Davidson, Geologist II

Eugenia E. Kelley, Staff Assistant V

Frances A. Benson, Staff Assistant IV

Luanne Davis, Staff Assistant IV

Kimberly B. Stroth, Staff Assistant IV

\section{GEOLOGICAL DIVISION}

Coal and Minerals Section:

Donald R. Chesnut, Jr., Acting Head

Garland R. Dever, Jr., Geologist VII

Cortland F. Eble, Geologist V

David A. Williams, Geologist V, Henderson Office

Warren H. Anderson, Geologist IV

Gerald A. Weisenfluh, Geologist IV

Stephen F. Greb, Geologist III

Robert E. Andrews, Geologist I

Petroleum and Stratigraphy Section:

James A. Drahovzal, Head

Ronald L. Street, Associate Professor

Terence Hamilton-Smith, Geologist V

Patrick J. Gooding, Geologist IV

David C. Harris, Geologist IV

Brandon C. Nuttall, Geologist IV

Matthew Humphreys, Geologist II

Gerald J. Kinsella, Geologist I

Thomas N. Sparks, Geologist I

Anna E. Watson, Geologist I

Robert R. Daniel, Laboratory Technician B

Jay C. Ramsey, Laboratory Assistant

Theola L. Evans, Staff Assistant IV

Water Resources Section:

James S. Dinger, Head

James A. Kipp, Geologist V

Daniel I. Carey, Hydrologist IV

James C. Currens, Geologist IV

David R. Wunsch, Geologist IV

Alex W. Fogle, Hydrologist III

Philip G. Conrad, Geologist II

Gary K. Felton, Geologist II

Dwayne M. Keagy, Geologist II

Shelley A. Minns, Geologist II

C. Douglas R. Graham, Geological Technician

Timothy D. Montowski, Geological Technician

Kevin J. Wente, Geological Technician

Computer and Laboratory Services Section:

Steven J. Cordiviola, Head

Richard E. Sergeant, Geologist V

Joseph B. Dixon, Systems Programmer

James M. McElhone, Sr. Systems Analyst Programmer

Henry E. Francis, Associate Scientist

Karen Cisler, Senior Research Analyst

Steven R. Mock, Research Analyst

Alice D. Taylor, Research Analyst

Mark F. Thompson, Research Analyst

Tammie J. Heazlit, Senior Laboratory Technician 


\section{CONTENTS}

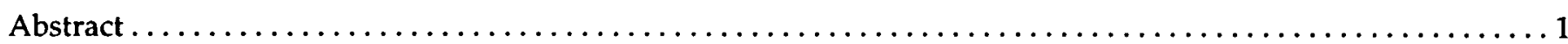

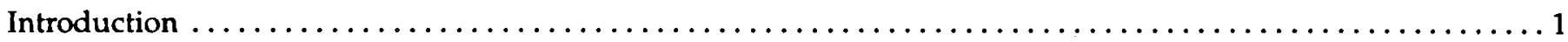

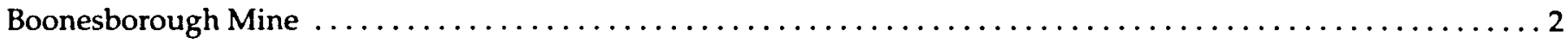

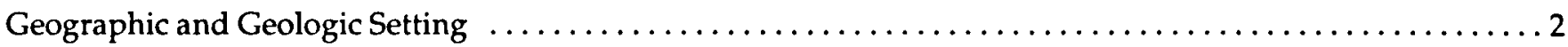

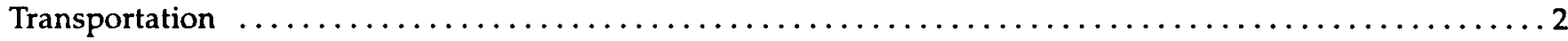

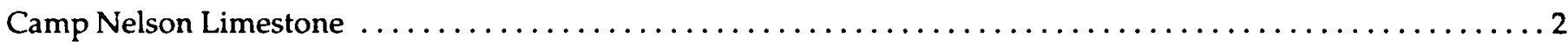

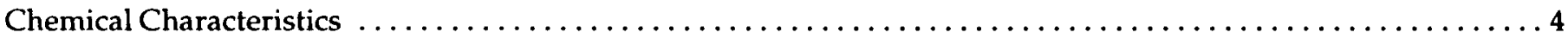

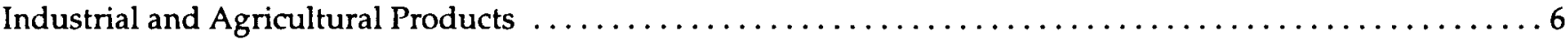

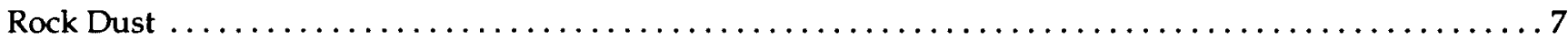

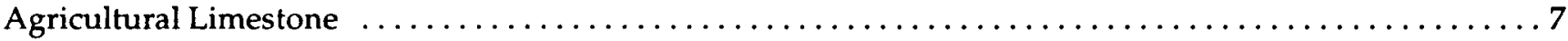

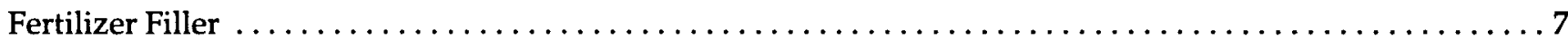

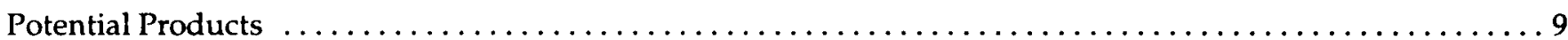

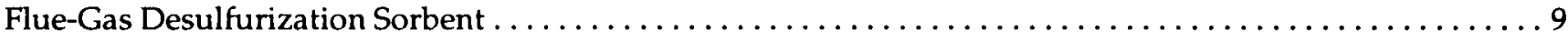

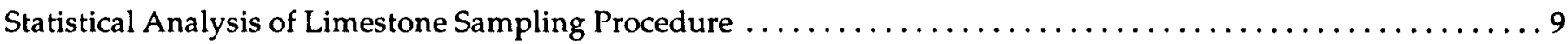

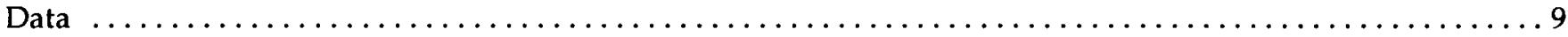

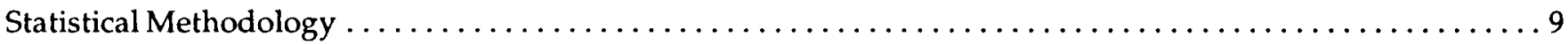

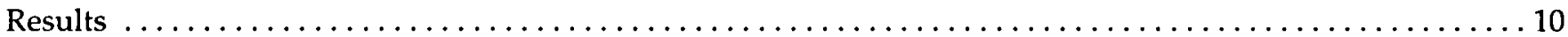

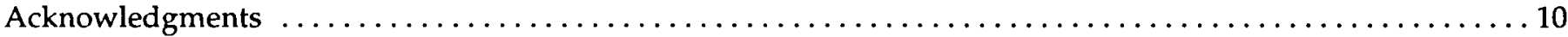

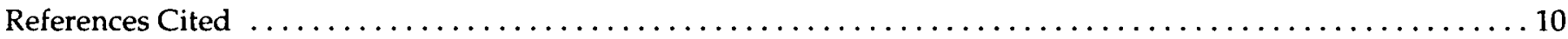

APPENDIX A: Major-Element Analyses and Lithologic Descriptions of Camp Nelson Limestone in

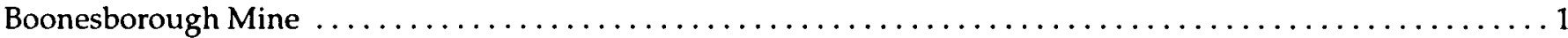
13

\section{ILLUSTRATIONS}

Figure

1. Map of central Kentucky, showing location of Boonesboro Quarry Division mine at Boonesborough, nearby mines producing stone from Camp Nelson Limestone, ASARCO core hole, and transportation

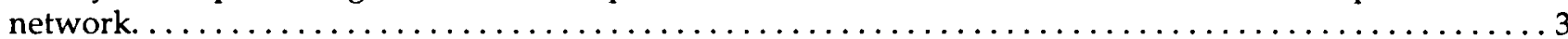

2. Map showing main outcrop area of High Bridge Group rocks, principal fault systems, and active mines. . 4

3. Main entry to room-and-pillar mine in Camp Nelson Limestone at Boonesborough. $\ldots \ldots \ldots \ldots \ldots$

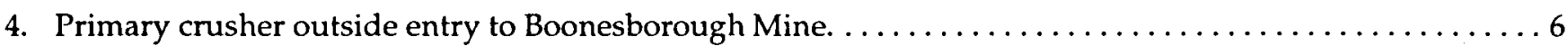

5. Generalized cross section showing structural setting of Camp Nelson Limestone (shaded) and mine at

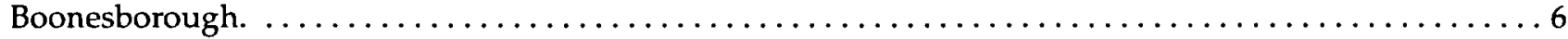

6. Spartan Rock Products plant, adjacent to Boonesborough Mine $\ldots \ldots \ldots \ldots \ldots \ldots \ldots \ldots \ldots \ldots \ldots$

7. Stratigraphic position of low-silica and high-carbonate intervals in sampled sections from ASARCO core, Fayette County (Dever, 1980), and Boonesborough Mine, Madison County (this report) . .......8 


\section{TABLES}

Table

Page

1. Average values for foot-by-foot analyses of low-silica and high-carbonate intervals in Camp Nelson

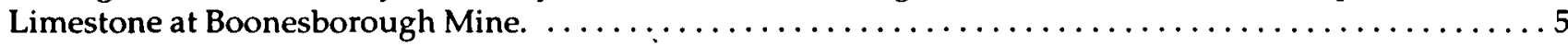

2. Variance components and intra-class correlations by site and end point. $\ldots \ldots \ldots \ldots \ldots \ldots \ldots \ldots$

3. Number of samples needed per ledge to obtain selected reliability for the mean carbonate (or contaminant). 


\title{
CHEMICAL AND STATISTICAL ANALYSIS OF A SAMPLED INTERVAL IN THE CAMP NELSON LIMESTONE (UPPER ORDOVICIAN), MADISON COUNTY, CENTRAL KENTUCKY
}

\author{
Garland R. Dever, Jr., Warren H. Anderson, \\ Henry E. Francis, O. Barton Davidson, \\ and Mark F. Thompson
}

\begin{abstract}
The Camp Nelson Limestone of the High Bridge Group (Upper Ordovician) is mined at seven sites in central and north-central Kentucky for industrial, construction, and agricultural uses. As part of a regional investigation of its chemical characteristics, a 67-foot section in the upper Camp Nelson, which is being mined at Boonesborough, Madison County, was sampled for major-element analysis.

The upper Camp Nelson in the Boonesborough Mine consists of two zones ( 23 and 30 feet thick) of low-silica stone (4 percent or less total $\mathrm{SiO}_{2}$ ) separated by a 14 -foot section of slightly argillaceous limestone with an average silica content of 5.19 percent. The lower 23 -foot zone has an average silica content of 1.75 percent and an average total carbonate $\left(\mathrm{CaCO}_{3}+\mathrm{MgCO}_{3}\right)$ content of 96.03 percent. The upper 30 -foot zone has an average silica content of 2.48 percent and an average total carbonate content of 93.17 percent.

A statistical study showed a relationship between the sampling interval and the reliability of the mean carbonate (or contaminant) value for a limestone ledge. Moderately high reliability ( 0.80 to 0.85 ) can be obtained by taking three to four samples per ledge. If only high reliability $(0.90)$ of the mean value is acceptable, samples should be taken at 1 -foot intervals. Very high reliability would require sampling at $1 / 2$-foot intervals.
\end{abstract}

\section{INTRODUCTION}

The Camp Nelson Limestone (Upper Ordovician) is a thick ( 345 to 445 feet) body of limestone and dolomite mined at seven sites in central and north-central Kentucky for lime manufacture, construction aggregate, agricultural uses, and rock dust. The Kentucky Geological Survey is investigating the Camp Nelson to determine (1) its chemical characteristics across the region and (2) the geographic and stratigraphic distribution of chemically pure stone suitable for industrial uses (Dever, 1974, 1980, 1981; Anderson and Barron, in press).

The upper Camp Nelson is being mined at Boonesborough in Madison County. The mine section was sampled at 1-foot intervals for major-element analysis in order to (1) obtain additional data on the chemical quality of the Camp Nelson in central Kentucky and (2) provide data for a statistical analysis of limestone sampling procedures and their effectiveness in characterizing a deposit.

This report presents major-element analyses for the foot-by-foot samples taken from the Camp Nelson section at Boonesborough. The sampled section contains zones of low-silica and high-carbonate stone. Results of the statistical study show a relationship between the sampling interval and the reliability for the mean carbonate (or contaminant) value of a limestone ledge.

In this publication, low-silica stone designates carbonate rocks with a total (free and combined) silicon dioxide $\left(\mathrm{SiO}_{2}\right)$ content of 4 percent or less. High-carbonate stone designates carbonate rocks composed of 95 percent or more total carbonates, calcium carbonate 
plus magnesium carbonate $\left(\mathrm{CaCO}_{3}+\mathrm{MgCO}_{3}\right)$. Highcalcium limestone designates carbonate rocks composed of 95 percent or more calcium carbonate $\left(\mathrm{CaCO}_{3}\right)$. The sampled section is divided vertically into ledges, which are units of lithologically similar limestone.

\section{BOONESBOROUGH MINE Geographic and Geologic Setting}

The Boonesborough limestone mine and plant, operated by the Boonesboro Quarry Division of The Allen Company, are located next to the Kentucky River in northern Madison County (Figs. 1-4). The geologic map of the Ford Quadrangle covers the site (Black, 1968).

The mine is on the upthrown (north) side of the eastwest-trending Kentucky River Fault System (Figs. 2, 5). Vertical displacement on a main fault extending along the south side of the mine is about 360 feet (Black, 1968). The Kentucky River Fault System consists of numerous faults, which have multiple components of movement and have undergone multiple episodes of faulting (Black, 1968; Haney, 1974; Black and Haney, 1975; Gustafson, 1986; VanArsdale and Sergeant, 1987).

Downcutting by the Kentucky River on the upthrown side of the fault system has exposed resistant limestone and dolomite of the High Bridge Group (Upper Ordovician), including the upper part of the Camp Nelson Limestone (Black, 1968). Less resistant limestone, shale, and siltstone of younger Ordovician formations crop out on the downthrown (south) side.

The mine was driven horizontally into a cliff of Camp Nelson Limestone along the west bank of the river, between river miles 175 and 176 . Stone is produced by room-and-pillar mining. The main working face is 30 feet high. In part of the mine, an additional 40 feet of stone is being taken from below the main floor. Faults are present in the mine (Gustafson, 1986), but the section described in this report was sampled in the eastcentral part of the mine, at a site where no faults have been found.

The Camp Nelson Limestone at Boonesborough currently is being mined for construction aggregate, agricultural limestone (aglime), fertilizer filler, and derrick stone. The operation also supplies stone for Spartan Rock Products, which has a plant adjacent to the mine (Fig. 6). The Spartan plant produces low-silica rock dust for underground coal mines, and agricultural limestone, including finely ground aglime suitable for hydroseeders used in mine reclamation.

\section{Transportation}

The mine is adjacent to Kentucky Highway 627, which furnishes access to the network of State and Federal highways in central Kentucky (Fig. 1). Interstate Highway 75 (Interchange 95) is 6 miles to the southwest, and Interstate Highway 64 (Interchange 94) at Winchester is 9.5 miles to the northeast. A main line of the CSX Transportation railroad system passes through the community of Ford, 2.3 miles south of the mine via Kentucky Highway 1924.

The mining operation also has a barge-loading facility on the Kentucky River. Stone from the mine presently is being transported by barge for use in a project to repair and upgrade the condition of dams on the river. The dock is between river miles 174 and 175, on the pool between Lock and Dam 9 (Valley View) and Lock and Dam 10 (Boonesborough). In recent years, the Kentucky River generally has not been used for commercial barge traffic above Frankfort, which is served by Lock and Dam 4.

\section{CAMP NELSON LIMESTONE}

The Camp Nelson Limestone is part of the High Bridge Group (Upper Ordovician), which consists of three formations: in descending order, the Tyrone Limestone, Oregon Formation, and Camp Nelson Limestone (Fig. 7). Thicknesses and principal lithologies for High Bridge units in the area were reported by Black (1968) and Dever (1980): (1) Tyrone, 55 to 90 feet, micrograined limestone; (2) Oregon, 30 to 65 feet, finely crystalline dolomite; and (3) Camp Nelson, as much as 442 feet, micrograined limestone mottled with dolomite.

The top of the section sampled in the Boonesborough Mine is about 20 feet below the top of the Camp Nelson. This calculated position is based on geologic mapping by Black (1968) and the results of an altimeter survey conducted during the present investigation.

The Camp Nelson in the mine mainly consists of micrograined to very fine-grained limestone, mottled with small, irregular bodies and thin seams of very finely crystalline dolomite (Appendix A). The limestone commonly has a subconchoidal fracture, contains scattered fossil fragments, and is stylolitic. Lesser amounts of very fine- to very coarse-grained, intraclastic, bioclastic, pelletal limestone are interlayered with the micrograined limestone. A slightly argillaceous, very finely crystalline, dolomitic limestone is the dominant lithology near the middle of the sampled section. 


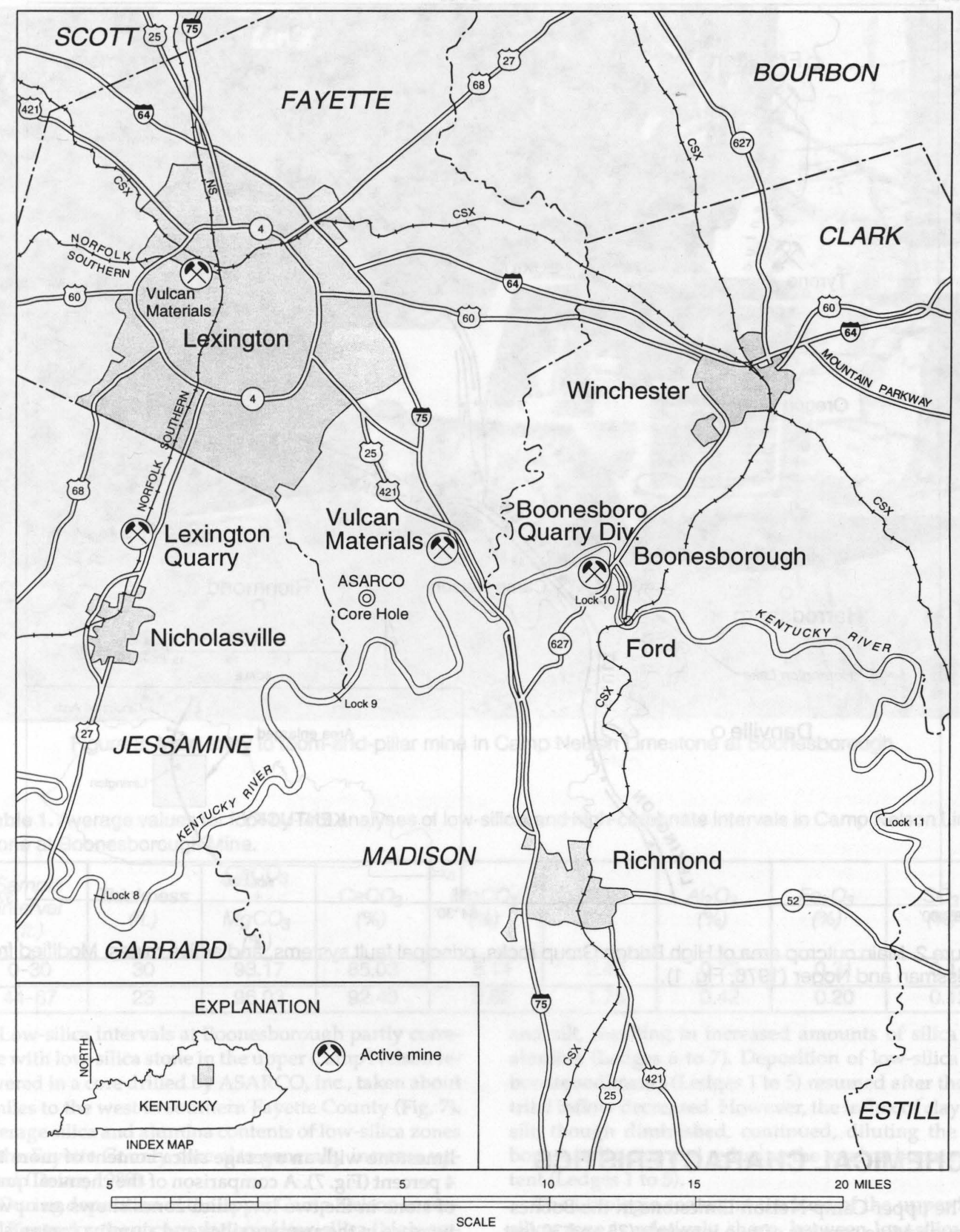

Figure 1. Central Kentucky, with location of Boonesboro Quarry Division mine at Boonesborough, nearby mines producing stone from Camp Nelson Limestone, ASARCO core hole, and transportation network. 


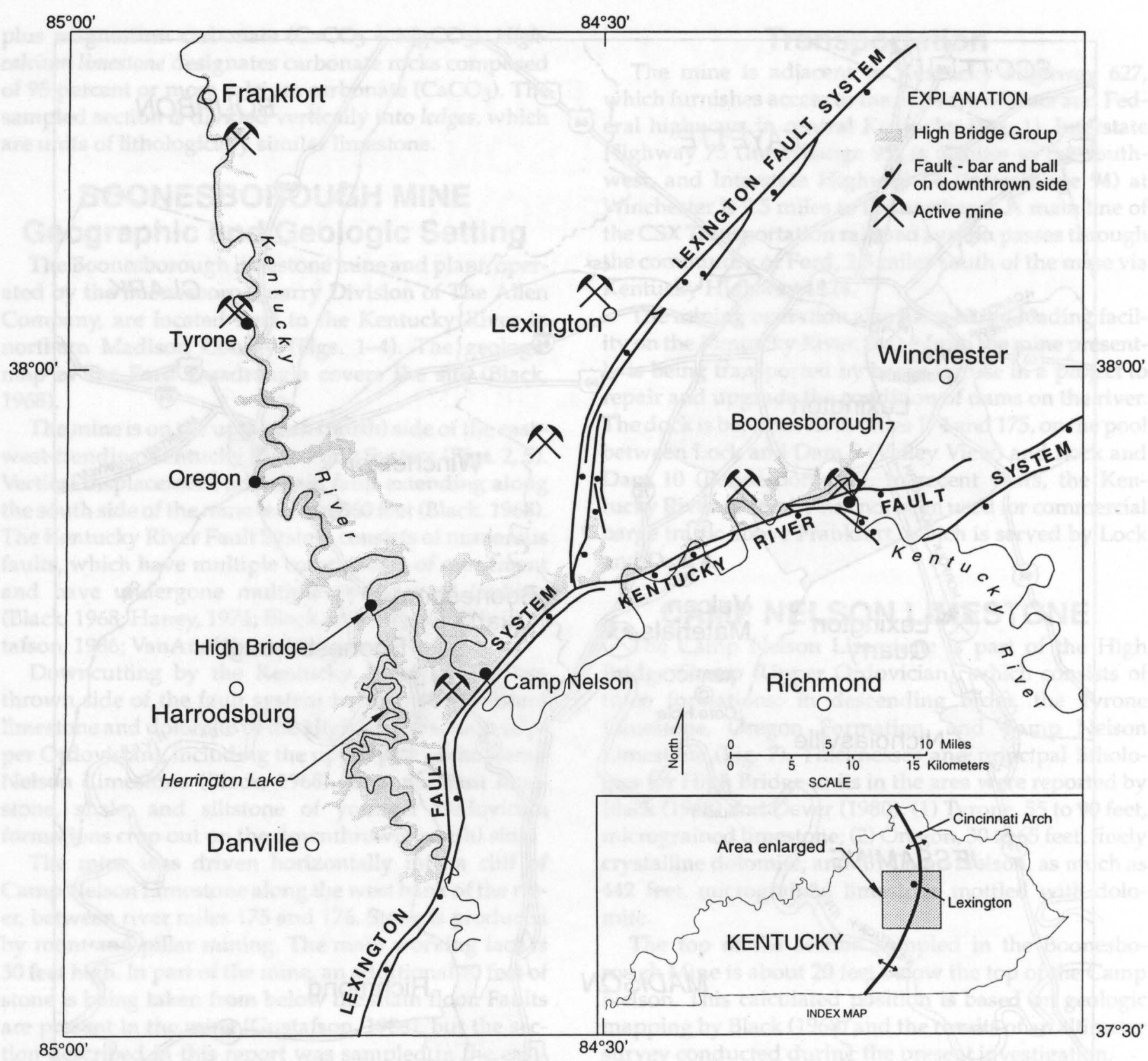

Figure 2. Main outcrop area of High Bridge Group rocks, principal fault systems, and active mines. Modified from Cressman and Noger (1976, Fig. 1).

\section{CHEMICAL CHARACTERISTICS}

The upper Camp Nelson Limestone in the Boonesborough Mine consists of two intervals ( 23 and 30 feet thick) of low-silica stone ( 4 percent or less total $\mathrm{SiO}_{2}$ ) separated by a 14 -foot section of slightly argillaceous limestone with an average silica content of more than 4 percent (Fig. 7). A comparison of the chemical quality of stone in the two low-silica zones shows an upward increase in the average silica and alumina contents and a decrease in the average total carbonate content (Table 1). 


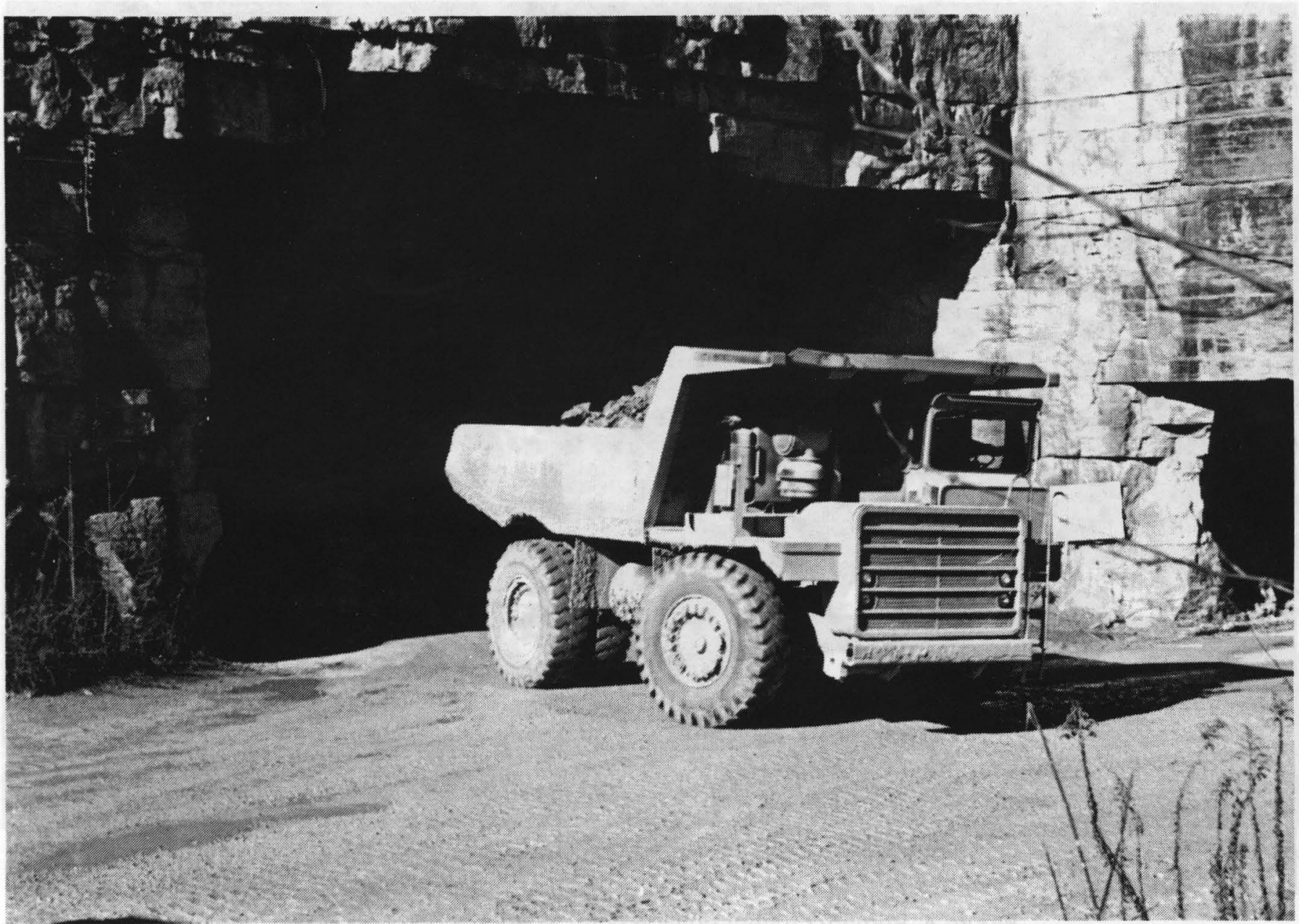

Figure 3. Main entry to room-and-pillar mine in Camp Nelson Limestone at Boonesborough.

Table 1. Average values for foot-by-foot analyses of low-silica and high-carbonate intervals in Camp Nelson Limestone at Boonesborough Mine.

\begin{tabular}{|c|c|c|c|c|c|c|c|c|}
\hline $\begin{array}{c}\text { Sample } \\
\text { Interval } \\
\text { (ft.) }\end{array}$ & $\begin{array}{c}\text { Thickness } \\
\text { (ft.) }\end{array}$ & $\begin{array}{c}\mathrm{CaCO}_{3} \\
+ \\
\mathrm{MgCO}_{3} \\
\text { (\%) }\end{array}$ & $\begin{array}{c}\mathrm{CaCO}_{3} \\
\text { (\%) }\end{array}$ & $\begin{array}{c}\mathrm{MgCO}_{3} \\
\text { (\%) }\end{array}$ & $\begin{array}{c}\mathrm{SiO}_{2} \\
\text { (\%) }\end{array}$ & $\begin{array}{c}\mathrm{Al}_{2} \mathrm{O}_{3} \\
\text { (\%) }\end{array}$ & $\begin{array}{c}\mathrm{Fe}_{2} \mathrm{O}_{3} \\
\text { (\%) }\end{array}$ & $\begin{array}{c}\mathrm{SO}_{3} \\
\text { (\%) }\end{array}$ \\
\hline $0-30$ & 30 & 93.17 & 85.03 & 8.14 & 2.48 & 0.73 & 0.31 & 0.14 \\
\hline $44-67$ & 23 & 96.03 & 92.40 & 3.62 & 1.75 & 0.42 & 0.20 & 0.12 \\
\hline
\end{tabular}

Low-silica intervals at Boonesborough partly correlate with low-silica stone in the upper Camp Nelson recovered in a core drilled by ASARCO, Inc., taken about 8 miles to the west in southern Fayette County (Fig. 7). Average silica and alumina contents of low-silica zones in the Fayette County core also generally increase upward (Dever, 1980).

During deposition of the upper Camp Nelson in central Kentucky, the accumulation of low-silica/high-carbonate sediments (Ledges 8 to 11, Appendix A) was interrupted by an influx of water- and wind-borne clay and silt, resulting in increased amounts of silica and alumina (Ledges 6 to 7). Deposition of low-silica carbonate sediments (Ledges 1 to 5 ) resumed after the detrital inflow decreased. However, the influx of clay and silt, though diminished, continued, diluting the carbonate sediments and reducing the total carbonate content (Ledges 1 to 5 ).

The lithologic contact at the base of the upper lowsilica zone is relatively sharp, between low-silica micrograined limestone (mottled with dolomite) (Ledges 1 to 5 ; Appendix A) and slightly argillaceous, very fine- 


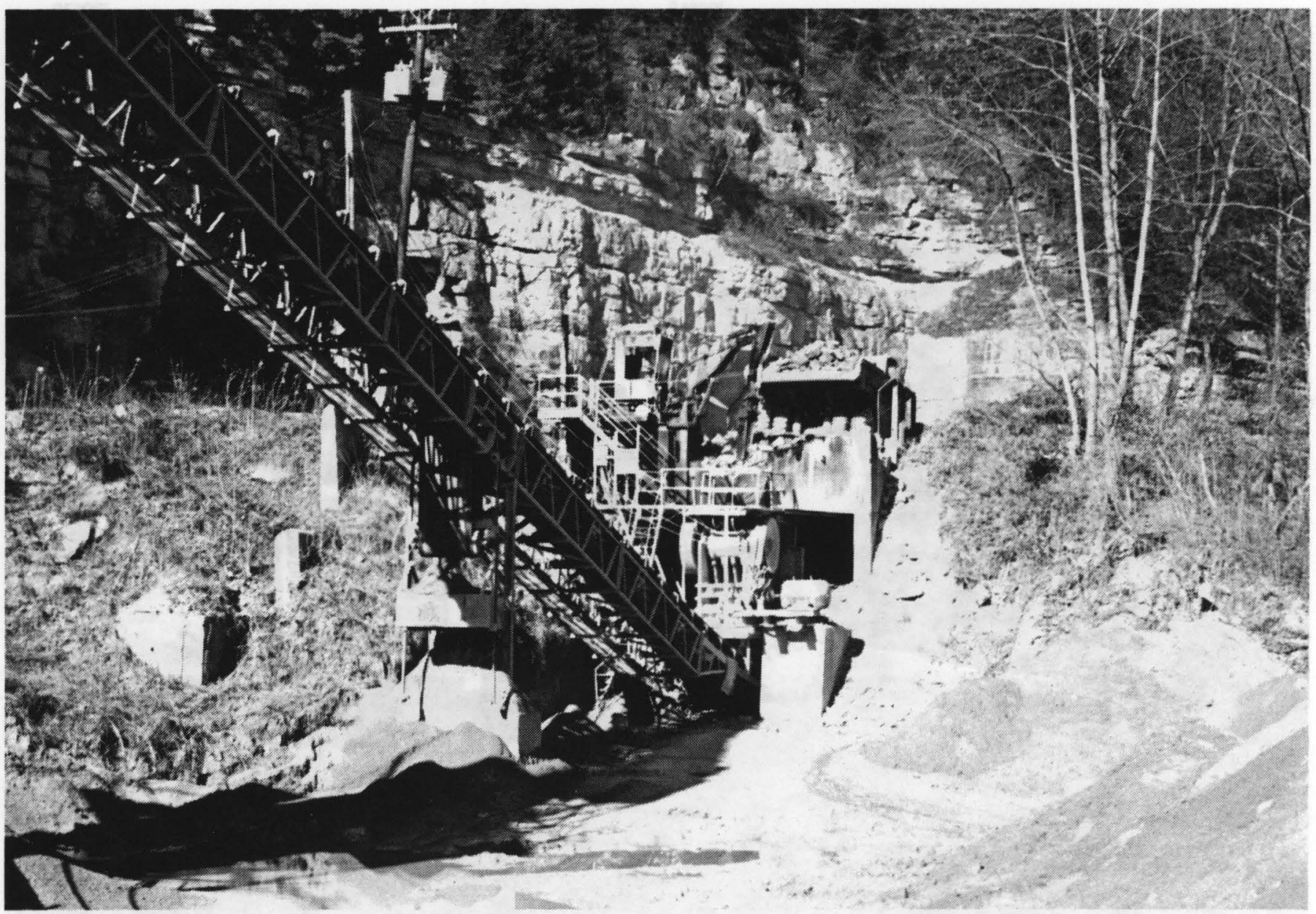

Figure 4. Primary crusher outside entry to Boonesborough Mine.

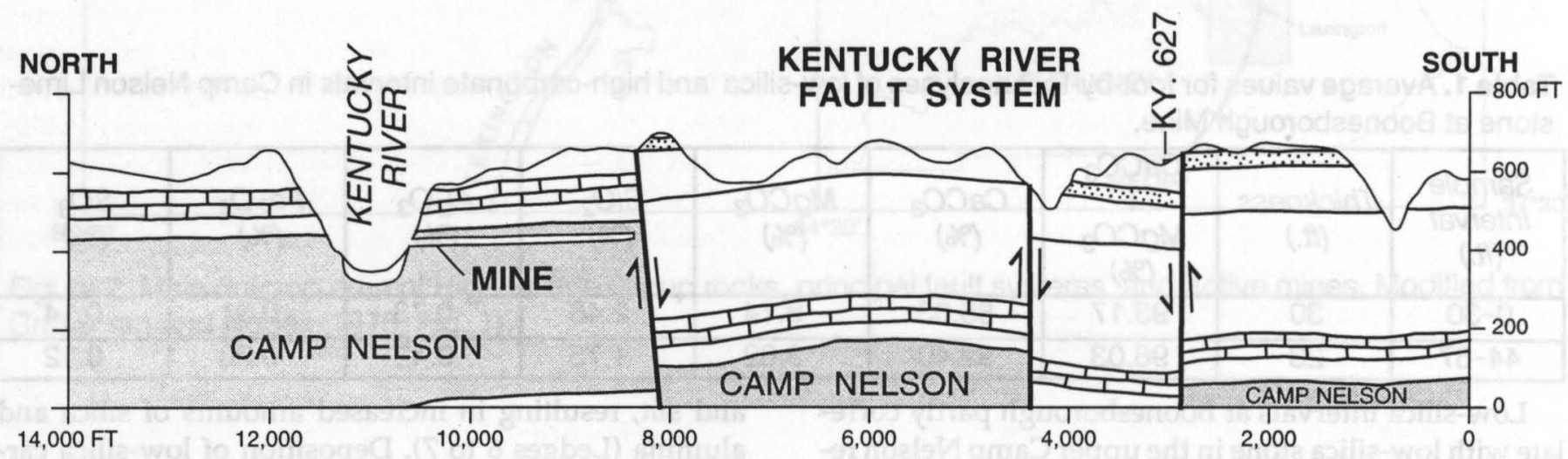

Figure 5. Generalized cross section showing structural setting of Camp Nelson Limestone (shaded) and mine at Boonesborough. Modified from Black (1968).

ly crystalline, dolomitic limestone (with lenses and layers of micrograined limestone) (Ledges 6 to 7 ). The contact at the top of the lower low-silica zone apparently is gradational, between low-silica micrograined to very coarse-grained limestone (mottled with dolomite) (Ledges 8 to 11 ) and slightly argillaceous, very finely crystalline dolomite, interlayered with micrograined limestone (Ledges 6 to 7 ).

\section{Industrial and Agricultural Products}

Three products currently made at the Boonesboro Quarry Division plant and the adjacent Spartan Rock 


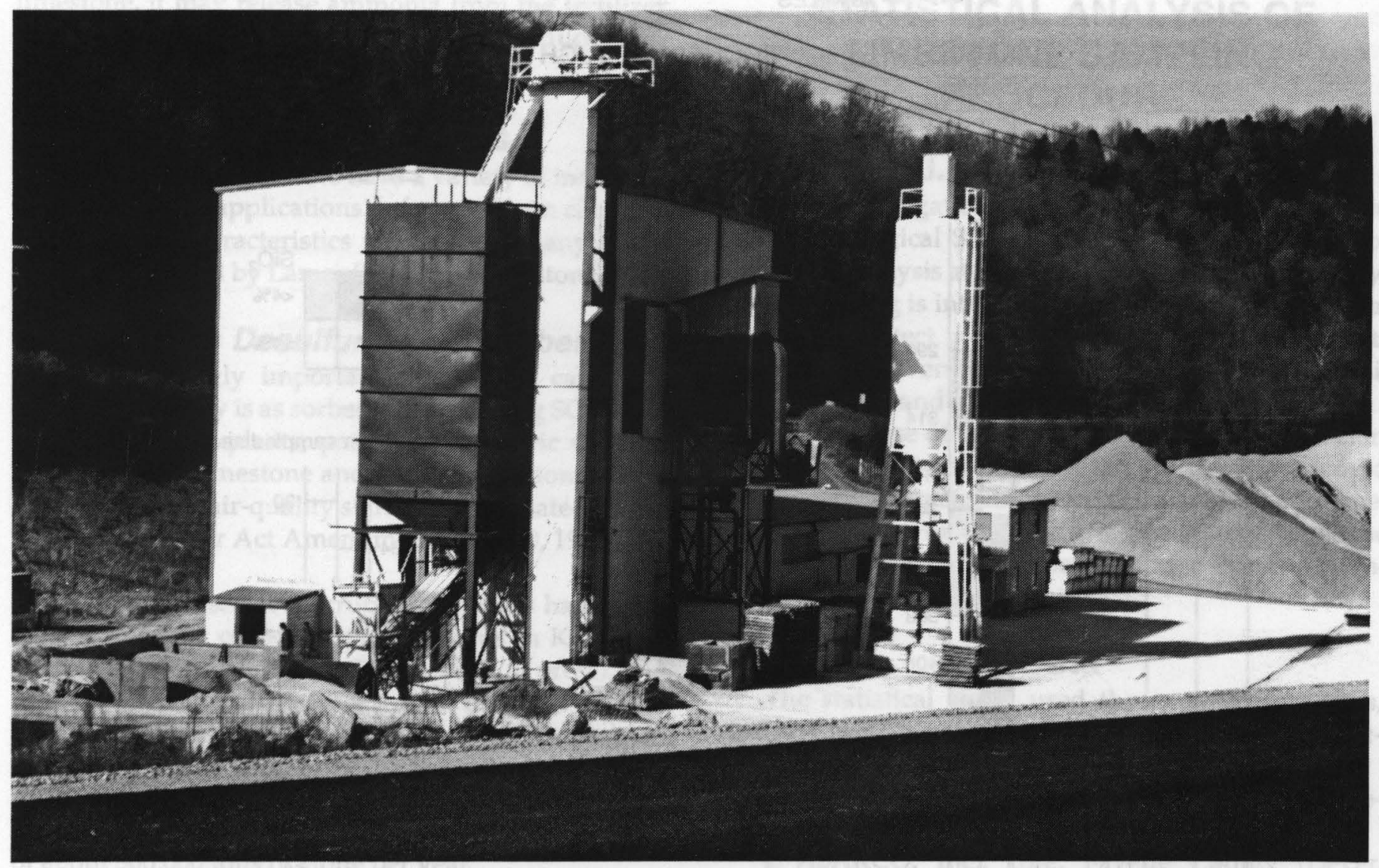

Figure 6. Spartan Rock Products plant, adjacent to Boonesborough Mine. Plant produces rock dust and agricultural limestone from stone supplied by mine.

Products plant are based mainly on the chemical quality of the Camp Nelson Limestone: rock dust, agricultural limestone, and fertilizer filler.

\section{Rock Dust}

Pulverized limestone, dolomite, and other inert materials used as rock dust for explosion abatement in underground coal mines must meet Federal specifications for silica $\left(\mathrm{SiO}_{2}\right)$ content, in order to reduce the potential for silicosis through inhalation by miners (Boynton, 1980). The Federal Coal Mine Health and Safety Act of 1969, Public Law 91-173, states that these materials are not to contain more than a total of 4 percent free and combined silica (Federal Register Office, 1970).

\section{Agricultural Limestone}

Agricultural limestone is applied to soils and mine spoils to adjust their $\mathrm{pH}$ for plant growth and to enhance the supply of nutrients. Carbonate rocks used for agricultural stone in Kentucky must have a minimum calcium carbonate equivalent (CCE) value of 80 . An arbitrary CCE value of 100 is assigned to pure limestone, composed of 100 percent calcium carbonate $\left(\mathrm{CaCO}_{3}\right)$. Pure dolomite $\left[\mathrm{CaMg}\left(\mathrm{CO}_{3}\right)_{2}\right]$, which is composed of 54.3 percent $\mathrm{CaCO}_{3}$ and 45.7 percent $\mathrm{MgCO}_{3}$, has a CCE value of 108.6. Pure magnesium carbonate possesses a higher $C C E$ value than pure calcium carbonate because it has a lower molecular weight but the same neutralizing power per molecular unit as calcium carbonate (Boynton, 1980). The CCE value of a carbonate rock is the sum of its magnesium carbonate content multiplied by 1.19 , plus its calcium carbonate content multiplied by $1.00\left[\mathrm{CCE}=\left(\mathrm{MgCO}_{3} \times 1.19\right)+\mathrm{CaCO}_{3}\right]$.

\section{Fertilizer Filler}

Fertilizer compounders add dolomitic limestone to fertilizer to serve as a filler or diluent (Boynton, 1980). It also contributes calcium and magnesium as nutrients and neutralizes acidity from nitrogen compounds. High-calcium limestone rarely is used in mechanical fertilizer mixtures. Being more reactive than dolomitic 


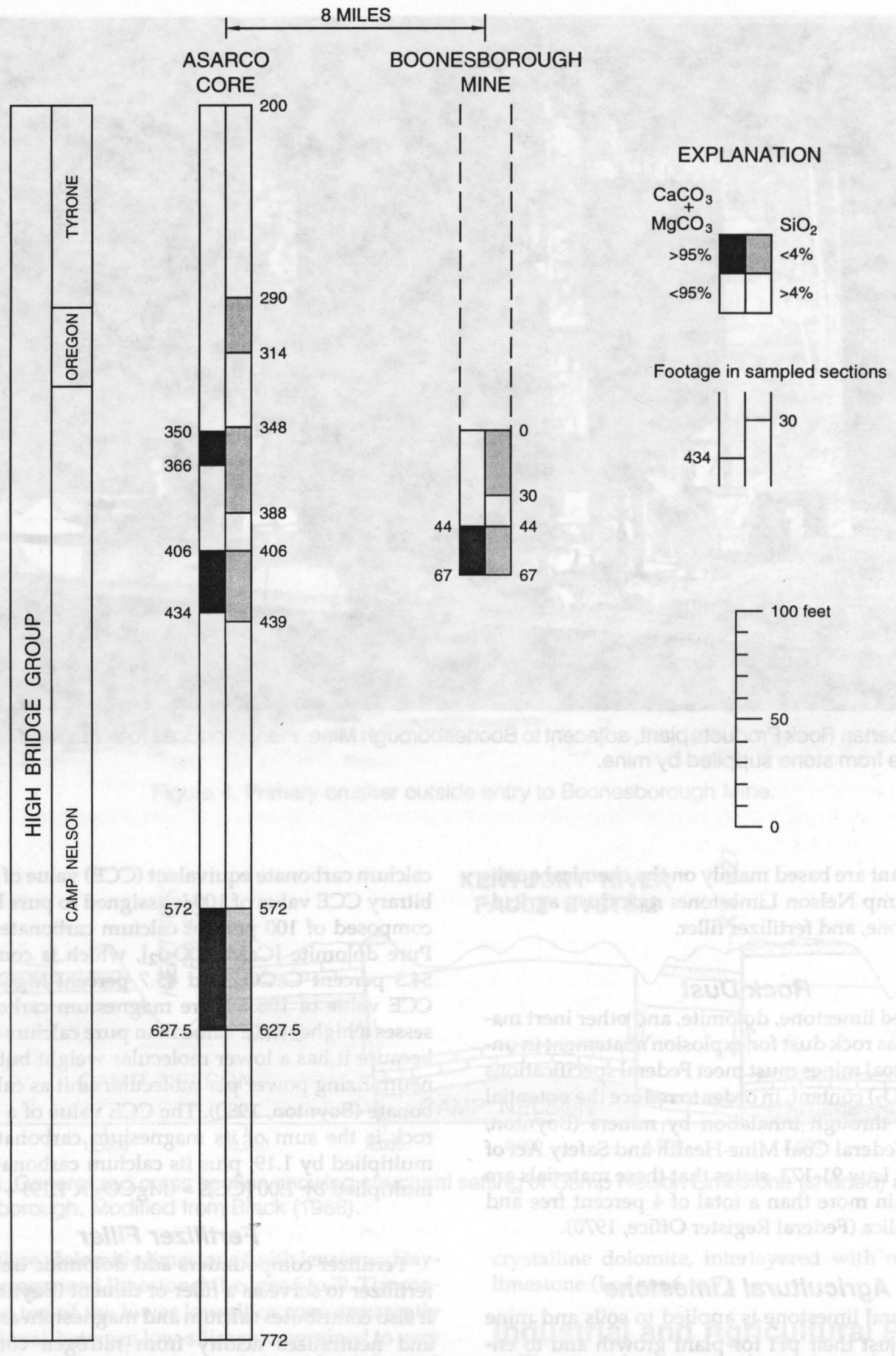

Figure 7. Stratigraphic position of low-silica and high-carbonate intervals in sampled sections from ASARCO core, Fayette County (Dever, 1980), and Boonesborough Mine, Madison County (this report). Locations shown in Figure 1. 
limestone, it may release ammonia from the fertilizer, and an excessive calcium content tends to reduce phosphorus availability (Boynton, 1980).

\section{Potential Products}

Limestone and dolomite have a variety of industrial and agricultural applications. Information on chemical and physical characteristics required for many of the uses are provided by Lamar (1961) and Boynton (1980).

\section{Flue-Gas Desulfurization Sorbent}

An increasingly important market for carbonate rocks in Kentucky is as sorbents for reducing $\mathrm{SO}_{2}$ emissions. Coal-fired plants, particularly electric utilities, are employing limestone and lime in emission-control systems to meet air-quality standards mandated by the Federal Clean Air Act Amendments of 1970, 1977, and 1990.

Limestone-based wet-scrubbing systems have been installed at four coal-fired power plants in Kentucky for flue-gas desulfurization (Dever, 1990, in press). The four plants currently require a total of about 830,000 tons of limestone a year. Two utilities presently are each retrofitting a coal-fired boiler with a limestone-based scrubbing system. These two scrubbers, scheduled to be on line by January 1995, will use an estimated total of about 300,000 tons of stone per year.

Electric utility specifications for limestone used in wet-scrubbing systems at Kentucky plants require a relatively high calcium carbonate content (minimum 88 to 90 percent $\mathrm{CaCO}_{3}$ ) and a low magnesium carbonate content (maximum 4 to 6 percent $\mathrm{MgCO}_{3}$ ) (Dever, 1990, in press). In general, limestone with a higher calcium carbonate content is more reactive and more efficient in capturing $\mathrm{SO}_{2}$ emissions. Utility specifications commonly include maximum allowable contents for noncarbonate constituents in the limestone: 3.5 to 5.0 percent silica $\left(\mathrm{SiO}_{2}\right) ; 1.2$ to 6.0 percent aluminum and iron oxides $\left(\mathrm{Al}_{2} \mathrm{O}_{3}+\mathrm{Fe}_{2} \mathrm{O}_{3}\right) ; 1.0$ percent alkalies $\left(\mathrm{Na}_{2} \mathrm{O}+\right.$ $\left.\mathrm{K}_{2} \mathrm{O}\right) ; 0.3$ percent sulfur $(\mathrm{S}) ; 0.03$ percent chlorine $(\mathrm{Cl})$; and 0.03 percent fluorine (F).

Limestone grindability also is specified, generally as a maximum Bond Work Index of 11 or 12 . The limestone must be finely ground (commonly 90 percent minus 325 mesh) to efficiently blend with water to form a slurry.

The 23-foot zone of high-carbonate limestone in the Boonesborough Mine generally meets the chemical specifications for scrubber stone being used at Kentucky power plants (Table 1, Appendix A). If coal-fired boilers at generating stations and industrial plants in central Kentucky are retrofitted with limestone-based wet-scrubbing systems, the Camp Nelson would be a potential source of sorbent stone.

\section{STATISTICAL ANALYSIS OF LIMESTONE SAMPLING PROCEDURE}

\section{Richard J. Kryscio and Diane Davis}

In its investigations of limestone resources, the Kentucky Geological Survey generally takes samples for chemical analysis at 1-foot intervals. The use of foot-byfoot sampling is intended to provide sufficient vertical control to detect increases in deleterious constituents that would adversely affect the suitability of a deposit for industrial and agricultural uses.

The purpose of this statistical analysis was to determine if sampling at intervals larger than 1 foot would adequately characterize the chemical quality of a limestone deposit. For this study, it was assumed that the objective of sampling was to determine the mean composition of a ledge of limestone.

\section{Data}

The statistical study used the percent carbonates, percent contaminants, and ledge numbers for the footby-foot samples from two central Kentucky sites:

1. Boonesborough Mine, Madison County (this report) and

2. ASARCO, Inc., core, Fayette County (Dever, 1980) (see Figs. 1 and 7, this report).

The basic data set consisted of the percent composition of calcium carbonate $\left(\mathrm{CaCO}_{3}\right)$, magnesium carbonate $\left(\mathrm{MgCO}_{3}\right)$, silica $\left(\mathrm{SiO}_{2}\right)$, alumina $\left(\mathrm{Al}_{2} \mathrm{O}_{3}\right)$, and iron oxide $\left(\mathrm{Fe}_{2} \mathrm{O}_{3}\right)$ for each foot-by-foot sample taken from vertical transects at the two sites. The samples had been clustered into lithologically homogenous units, designated as ledges, which were numbered sequentially from the top to the bottom of the vertical transect. A lithologic description was available for each ledge, but it was not used in the study.

For purposes of this statistical analysis, the chemical composition was summarized as two components:

1. carbonates, equal to the sum of the percent composition of $\mathrm{CaCO}_{3}$ and $\mathrm{MgCO}_{3}$, and

2. contaminants, equal to the sum of the percent composition of $\mathrm{SiO}_{2}, \mathrm{Al}_{2} \mathrm{O}_{3}$, and $\mathrm{Fe}_{2} \mathrm{O}_{3}$.

This study ignored the sulfur oxide $\left(\mathrm{SO}_{3}\right)$ analyses for the Boonesborough samples, and sulfur (S) and phosphorus (P) analyses for the ASARCO samples.

\section{Statistical Methodology}

First, the goal of determining whether ledges could be sampled at intervals larger than 1 foot was defined more precisely. To this end, it was assumed that an important objective of the sampling is to determine the 
mean composition of the limestone in a randomly selected ledge. The problem is then reduced to determining the optimal number of samples needed to estimate the mean reliably by taking into account (1) the between-ledge variability and (2) the within-ledge (i.e., foot-by-foot sample) variability. This allows the statistician to estimate $r$, the intra-class correlation coefficient (the correlation between two randomly selected measurements of the carbonate or the contaminant in the same ledge). This correlation is related to the reliability of the mean of $m$ measurements made on the same ledge. For this analysis, the number of measurements required to obtain a targeted reliability, $R$, for the mean is related to $r$ by the formula:

$$
m=R(1-r) / r(1-R)
$$

Hence, if the desired reliability of the mean is known (i.e., $R$ ), then $m$, the number of measurements required to attain that reliability, can be determined.

This formulation of the problem assumes that samples within a ledge are randomly selected and are not necessarily selected at 1 -foot intervals. Systematic sampling and random sampling are reasonably equivalent, provided there are no trends in the population, which in this case is true, and provided there are no trends in the magnitude of the carbonates or the contaminants along the sampled transect.

\section{Results}

Table 2 lists the estimates of the between-ledge and within-ledge variance components and the intra-class correlation for each of the two sites and for each end point. These values were obtained by using an analysis of variance procedure for an unbalanced two-stage nested design.

Table 2. Variance components and intra-class correlations by site and end point.

\begin{tabular}{|l|l|c|r|c|}
\hline \multirow{2}{*}{ Site } & \multirow{2}{*}{ End Point } & \multicolumn{2}{|c|}{$\begin{array}{c}\text { Variance } \\
\text { Component }\end{array}$} & \multirow{2}{*}{$\begin{array}{l}\text { Intra-Class } \\
\text { Correlation }\end{array}$} \\
\cline { 3 - 4 } & & Between & Within & \\
\hline \multirow{2}{*}{ Boonesborough } & Carbonate & 5.71 & 2.50 & 0.70 \\
& Contaminant & 3.98 & 2.53 & 0.61 \\
\hline \multirow{2}{*}{ ASARCO } & Carbonate & 26.69 & 18.66 & 0.59 \\
& Contaminant & 22.43 & 14.78 & 0.60 \\
\hline
\end{tabular}

The data are more variable at the ASARCO site than at the Boonesborough site. This could be due to a difference in the sample size (633 versus 67 ) at the sites or a relative lack of homogeneity in the limestone itself at the ASARCO site. In either case, despite these differences, the intra-class correlation is relatively stable across sites and end points.
Table 3 lists the number of samples required to estimate the mean carbonate (or contaminant) level for a typical ledge at either site, assuming $r$ is approximately 0.59 (worst case scenario).

Table 3. Number of samples needed per ledge to obtain selected reliability for the mean carbonate (or contaminant).

\begin{tabular}{|c|c|}
\hline$R$ & $m^{\star}$ \\
\hline 0.75 & 3 \\
\hline 0.80 & 3 \\
\hline 0.85 & 4 \\
\hline 0.90 & 7 \\
\hline 0.95 & 14 \\
\hline *Rounded up to the nearest integer \\
\hline
\end{tabular}

Very high reliability ( 0.95 or above) can be attained only by taking 14 or more samples per ledge, while moderately high reliability $(0.80$ to 0.85$)$ can be obtained by taking three to four samples per ledge. These estimates should be compared to the average number of samples taken per ledge at each site: six samples per ledge at Boonesborough, and seven samples per ledge at the ASARCO location. If moderately high reliability is acceptable, then it is possible to space the sampling for a typical ledge farther apart than 1-foot intervals. But, if only high reliability $(R=0.90)$ is acceptable, no change should be made in the current sampling procedure. In a case when very high reliability is desirable, more closely spaced sampling (every $1 / 2$ foot) than currently practiced could be required.

\section{ACKNOWLEDGMENTS}

Wilgus Fox, Ralph Little, and Hugh Gabbard of The Allen Company provided assistance during sampling and field investigations. Samples were analyzed by Henry E. Francis and Mark F. Thompson at the Kentucky Geological Survey, using X-ray fluorescence.

The Kentucky Geological Survey is grateful to The Allen Company for allowing access to its mine for sampling and field studies. Without the cooperation of mineral producers, the Survey's investigation of mineral resources in Kentucky would be very limited. The knowledge gained from these investigations ultimately benefits all citizens of the Commonwealth.

\section{REFERENCES CITED}

Anderson, W.H., and Barron, L.S., in press, High-carbonate, low-silica, and high-calcium stone in the High Bridge Group (Upper Ordovician), Mason County, north-central Kentucky: Kentucky Geological Survey. 
Black, D.F.B., 1968, Geologic map of the Ford Quadrangle, central Kentucky: U.S. Geological Survey Geologic Quadrangle Map GQ-764.

Black, D.F.B., and Haney, D.C., 1975, Selected structural features and associated dolostone occurrences in the vicinity of the Kentucky River Fault System (Roadlog for Geological Society of Kentucky 1975 Field Conference): Kentucky Geological Survey, ser. $10,27 \mathrm{p}$.

Boynton, R.S., 1980, Chemistry and technology of lime and limestone ( $2 \mathrm{~d}$ ed.): New York, John Wiley and Sons, Inc., $578 \mathrm{p}$.

Cressman, E.R., and Noger, M.C., 1976, Tidal-flat carbonate environments in the High Bridge Group (Middle Ordovician) of central Kentucky: Kentucky Geological Survey, ser. 10, Report of Investigations $18,15 \mathrm{p}$.

Dever, G.R., Jr., 1974, High-carbonate rock in the High Bridge Group (Middle Ordovician), Boone County, Kentucky: Kentucky Geological Survey, ser. 10, Information Circular 22, $35 \mathrm{p}$.

Dever, G.R., Jr., 1980, High-carbonate and low-silica stone in the High Bridge Group (Middle Ordovician), Fayette County, central Kentucky: Kentucky Geological Survey, ser. 11, Information Circular 4, 45 p.

Dever, G.R., Jr., 1981, Carbonate-rock resources of the High Bridge Group (Middle Ordovician), central and north-central Kentucky, in Roberts, T.G., ed., GSA Cincinnati '81, Field trip guidebooks, volume
1: Stratigraphy, sedimentology: American Geological Institute, p. 9-12.

Dever, G.R., Jr., 1990, Use of limestone, lime, and dolomite for $\mathrm{SO}_{2}$ emission control in Kentucky: Kentucky Geological Survey, ser. 11, Information Circular 31, 14 p.

Dever, G.R., Jr., in press, The role of industrial minerals in controlling $\mathrm{SO}_{2}$ emissions from coal-fired plants in Kentucky, in Proceedings of 28th Forum on the Geology of Industrial Minerals: West Virginia Geological and Economic Survey.

Federal Register Office, 1970, Public Law 91-173, in United States statutes at large: Washington, D.C., U.S. Government Printing Office, v. 83, p. 742-804.

Gustafson, T.J., 1986, The structural geology of the Boonesboro limestone mine, Madison County, Kentucky: Richmond, Eastern Kentucky University, M.S. Thesis, $84 \mathrm{p}$.

Haney, D.C., 1974, Recurrent movement along the Kentucky River Fault System [abs.]: Geological Society of America Abstracts with Programs, v. 6, no. 4, p. 359-360.

Lamar, J.E., 1961, Uses of limestone and dolomite: Illinois State Geological Survey Circular 321, 44 p.

VanArsdale, R.B., and Sergeant, R.E., 1987, Post-Pliocene displacement on faults within the Kentucky River Fault System of east-central Kentucky: U.S. Nuclear Regulatory Commission NUREG/ CR-4685, 36 p.; 1992, Kentucky Geological Survey, ser. 11, Reprint 34 . 


\section{APPENDIX A: \\ Major-Element Analyses and Lithologic Descriptions of Camp Nelson Limestone in Boonesborough Mine}


County: Madison

Operator: Boonesboro Quarry Division of The Allen Company

Location: On north side of Kentucky Highway 627, at the Kentucky River, 6 miles northeast of Interstate Highway 75 (Interchange 95).

CHEMICAL ANALYSIS

\begin{tabular}{|c|c|c|c|c|c|c|c|}
\hline $\mathrm{CaCO}_{3}$ & $\stackrel{\%}{\%} \stackrel{\mathrm{CO}_{3}}{ }$ & $\begin{array}{c}\% \\
\mathrm{SiO}_{2}\end{array}$ & $\begin{array}{c}\% \\
\mathrm{Al}_{2} \mathrm{O}_{3}\end{array}$ & $\begin{array}{c}\% \\
\mathrm{Fe}_{2} \mathrm{O}_{3}\end{array}$ & $\begin{array}{c}\% \\
\mathrm{SO}_{3}\end{array}$ & $\begin{array}{c}\% \\
\text { TOTAL }\end{array}$ & $\begin{array}{c}\% \\
L O I\end{array}$ \\
\hline $\begin{array}{l}87.23 \\
87.25\end{array}$ & $\begin{array}{l}7.02 \\
6.93\end{array}$ & $\begin{array}{l}2.02 \\
2.13\end{array}$ & $\begin{array}{l}0.56 \\
0.59\end{array}$ & $\begin{array}{l}0.28 \\
0.29\end{array}$ & $\begin{array}{l}0.13 \\
0.13\end{array}$ & $\begin{array}{l}97.24 \\
97.32\end{array}$ & $\begin{array}{l}43.35 \\
43.32\end{array}$ \\
\hline $\begin{array}{l}86.48 \\
88.42 \\
90.26 \\
84.25 \\
84.67 \\
86.64 \\
88.44 \\
82.08\end{array}$ & $\begin{array}{l}6.63 \\
5.74 \\
4.79 \\
8.10 \\
9.24 \\
7.73 \\
6.81 \\
8.79\end{array}$ & $\begin{array}{l}3.10 \\
1.67 \\
1.56 \\
3.45 \\
2.14 \\
1.44 \\
1.24 \\
4.28\end{array}$ & $\begin{array}{l}0.92 \\
0.41 \\
0.36 \\
1.07 \\
0.51 \\
0.30 \\
0.26 \\
1.49\end{array}$ & $\begin{array}{l}0.34 \\
0.27 \\
0.24 \\
0.39 \\
0.30 \\
0.28 \\
0.25 \\
0.45\end{array}$ & $\begin{array}{l}0.17 \\
0.12 \\
0.10 \\
0.14 \\
0.10 \\
0.09 \\
0.07 \\
0.20\end{array}$ & $\begin{array}{l}97.64 \\
96.62 \\
97.30 \\
97.40 \\
96.97 \\
96.48 \\
97.07 \\
97.30\end{array}$ & $\begin{array}{l}42.72 \\
43.50 \\
43.37 \\
42.81 \\
43.53 \\
43.95 \\
43.82 \\
43.47\end{array}$ \\
\hline $\begin{array}{l}88.17 \\
87.26 \\
85.31 \\
77.50 \\
83.97 \\
82.79\end{array}$ & $\begin{array}{r}6.72 \\
6.95 \\
7.52 \\
10.57 \\
7.90 \\
9.38\end{array}$ & $\begin{array}{l}1.57 \\
2.04 \\
2.70 \\
5.83 \\
2.52 \\
2.74\end{array}$ & $\begin{array}{l}0.38 \\
0.61 \\
0.89 \\
2.22 \\
0.79 \\
0.83\end{array}$ & $\begin{array}{l}0.26 \\
0.26 \\
0.34 \\
0.59 \\
0.32 \\
0.33\end{array}$ & $\begin{array}{l}0.10 \\
0.10 \\
0.14 \\
0.23 \\
0.20 \\
0.15\end{array}$ & $\begin{array}{l}97.20 \\
97.21 \\
96.89 \\
96.93 \\
95.70 \\
96.22\end{array}$ & $\begin{array}{l}42.02 \\
43.17 \\
42.75 \\
41.48 \\
43.04 \\
42.94\end{array}$ \\
\hline $\begin{array}{l}82.24 \\
83.63 \\
82.05 \\
83.01 \\
83.83 \\
82.52 \\
85.07 \\
86.67 \\
86.03\end{array}$ & $\begin{array}{r}9.13 \\
9.10 \\
9.83 \\
9.01 \\
8.77 \\
10.16 \\
9.00 \\
7.92 \\
7.72\end{array}$ & $\begin{array}{l}3.89 \\
2.29 \\
3.33 \\
3.23 \\
2.32 \\
2.01 \\
1.44 \\
1.46 \\
2.32\end{array}$ & $\begin{array}{l}1.27 \\
0.62 \\
1.08 \\
1.08 \\
0.65 \\
0.45 \\
0.25 \\
0.25 \\
0.60\end{array}$ & $\begin{array}{l}0.41 \\
0.28 \\
0.37 \\
0.36 \\
0.29 \\
0.30 \\
0.27 \\
0.25 \\
0.27\end{array}$ & $\begin{array}{l}0.16 \\
0.15 \\
0.14 \\
0.18 \\
0.17 \\
0.16 \\
0.11 \\
0.11 \\
0.14\end{array}$ & $\begin{array}{l}97.11 \\
96.07 \\
96.80 \\
96.87 \\
96.03 \\
95.60 \\
96.15 \\
96.68 \\
97.07\end{array}$ & $\begin{array}{l}2.39 \\
43.28 \\
42.67 \\
42.50 \\
43.34 \\
43.78 \\
44.09 \\
43.89 \\
43.27\end{array}$ \\
\hline $\begin{array}{l}79.18 \\
86.00 \\
88.18 \\
85.80 \\
86.05\end{array}$ & $\begin{array}{r}10.54 \\
7.71 \\
7.29 \\
8.85 \\
8.38\end{array}$ & $\begin{array}{l}4.85 \\
1.97 \\
1.32 \\
1.70 \\
1.95\end{array}$ & $\begin{array}{l}1.80 \\
0.51 \\
0.25 \\
0.41 \\
0.51\end{array}$ & $\begin{array}{l}0.50 \\
0.27 \\
0.25 \\
0.26 \\
0.27\end{array}$ & $\begin{array}{l}0.26 \\
0.13 \\
0.10 \\
0.13 \\
0.12\end{array}$ & $\begin{array}{l}97.14 \\
96.60 \\
97.39 \\
97.14 \\
97.28\end{array}$ & $\begin{array}{l}42.01 \\
43.58 \\
43.87 \\
43.79 \\
43.45\end{array}$ \\
\hline
\end{tabular}


Carter Coordinate Location: sec. 2-Q-63 (Ford Quadrangle)

Sampled By: Garland R. Dever, Jr., Warren H. Anderson, and O. Barton Davidson

Analyzed By: Kentucky Geological Survey

Date Sampled: August 10-11, 1993

DESCRIPTION

\begin{tabular}{|c|c|c|c|}
\hline $\begin{array}{c}\text { Sample } \\
\text { Level } \\
\text { (feet) }\end{array}$ & $\begin{array}{c}\text { Ledge } \\
\text { No. }\end{array}$ & $\begin{array}{c}\text { Thickness } \\
\text { (feet) }\end{array}$ & Lithology \\
\hline & & & Mine ceiling; top of sampled section. \\
\hline $\begin{array}{l}0-1 \\
1-2\end{array}$ & 1 & 2 & $\begin{array}{l}\text { Limestone, yellowish-brown to dark-yellowish-brown, micrograined to } \\
\text { very fine-grained, with scattered coarser bioclastic grains and fossil frag- } \\
\text { ments (crinoid plates, brachiopods, and gastropods); mottled with small } \\
\text { irregular bodies and thin discontinuous seams of yellowish-gray to pale- } \\
\text { yellowish-brown, very finely crystalline dolomite; thin seams of fine- to } \\
\text { coarse-grained, bioclastic, pelletal limestone in upper foot; stylolitic; thick- } \\
\text { bedded; very thin irregular layers at top of ledge. }\end{array}$ \\
\hline $\begin{array}{l}2-3 \\
3-4 \\
4-5 \\
5-6 \\
6-7 \\
7-8 \\
8-9 \\
9-10\end{array}$ & 2 & 8 & $\begin{array}{l}\text { Limestone, very pale-yellowish-brown to pale-yellowish-brown, micro- } \\
\text { grained to very fine-grained, with scattered coarser bioclastic grains and } \\
\text { fossil fragments (brachiopods, bryozoans, and colonial corals-Tetradium), } \\
\text { subconchoidal fracture; interlayers and thin seams of medium-olive-gray to } \\
\text { very pale-yellowish-brown, very fine- to very coarse-grained, intraclastic, } \\
\text { bioclastic, pelletal limestone; mottled with small irregular bodies and thin } \\
\text { irregular seams of yellowish-gray to very light-olive-gray, and very pale- } \\
\text { yellowish-brown to dark-yellowish-brown, very finely crystalline dolo- } \\
\text { mite; stylolitic; massive to thick-bedded; partly thin-bedded in interval 5-6 } \\
\text { feet. }\end{array}$ \\
\hline $\begin{array}{l}10-11 \\
11-12 \\
12-13 \\
13-14 \\
14-15 \\
15-16\end{array}$ & 3 & 6 & $\begin{array}{l}\text { Limestone, pale-yellowish-brown to dark-yellowish-brown, micrograined, } \\
\text { with scattered coarser bioclastic grains and few fossil fragments (brachio- } \\
\text { pods), subconchoidal fracture; seams of very fine- to very coarse-grained, } \\
\text { intraclastic, bioclastic, pelletal limestone; mottled with small irregular bo- } \\
\text { dies and thin irregular seams of very pale-orange to dark-yellowish-brown, } \\
\text { and yellowish-gray to pale-grayish-orange, very finely crystalline dolo- } \\
\text { mite; stylolitic; massive to thick-bedded; prominent stylolitic parting at } 16 \\
\text { feet. }\end{array}$ \\
\hline $\begin{array}{l}16-17 \\
17-18 \\
18-19 \\
19-20 \\
20-21 \\
21-22 \\
22-23 \\
23-24 \\
24-25\end{array}$ & 4 & 9 & $\begin{array}{l}\text { Limestone, very pale-yellowish-brown to dark-yellowish-brown, micro- } \\
\text { grained, with small amount of coarser bioclastic grains and few fossil frag- } \\
\text { ments (crinoid plates and brachiopods), subconchoidal fracture; small } \\
\text { patches of very fine- to very coarse-grained, pelletal and bioclastic lime- } \\
\text { stone; mottled with small irregular bodies of yellowish-gray, and very pale- } \\
\text { orange to dark-yellowish-brown, very finely crystalline dolomite; stylolitic; } \\
\text { thick-bedded; prominent parting at } 25 \text { feet. }\end{array}$ \\
\hline $\begin{array}{l}25-26 \\
26-27 \\
27-28 \\
28-29 \\
29-30\end{array}$ & 5 & 5 & $\begin{array}{l}\text { Limestone, very pale-yellowish-brown to yellowish-brown, micrograined, } \\
\text { with small amount of coarser bioclastic grains and few fossil fragments, } \\
\text { subconchoidal fracture; mottled with small irregular bodies of very pale- } \\
\text { yellowish-brown to yellowish-brown, very finely crystalline dolomite; few } \\
\text { stylolites; thick-bedded. }\end{array}$ \\
\hline & & & Main mine floor at 30 feet. \\
\hline
\end{tabular}


CHEMICAL ANALYSIS

\begin{tabular}{|c|c|c|c|c|c|c|c|}
\hline$\stackrel{\%}{\mathrm{CaCO}_{3}}$ & $\stackrel{\%}{\%} \mathrm{CO}_{3}$ & $\begin{array}{c}\% \\
\mathrm{SiO}_{2}\end{array}$ & $\begin{array}{c}\% \\
\mathrm{Al}_{2} \mathrm{O}_{3}\end{array}$ & $\begin{array}{c}\% \\
\mathrm{Fe}_{2} \mathrm{O}_{3}\end{array}$ & $\begin{array}{c}\% \\
\mathrm{SO}_{3}\end{array}$ & $\begin{array}{c}\% \\
\text { TOTAL }\end{array}$ & LOI \\
\hline $\begin{array}{l}74.62 \\
76.85 \\
74.92 \\
70.03 \\
70.02 \\
74.92 \\
74.66 \\
71.02 \\
72.15 \\
77.25\end{array}$ & $\begin{array}{l}14.53 \\
13.53 \\
14.28 \\
17.01 \\
17.17 \\
14.77 \\
15.11 \\
16.93 \\
17.35 \\
13.95\end{array}$ & $\begin{array}{l}5.63 \\
4.49 \\
5.50 \\
7.65 \\
7.18 \\
5.16 \\
5.87 \\
6.62 \\
5.38 \\
3.76\end{array}$ & $\begin{array}{l}2.00 \\
1.44 \\
1.84 \\
2.66 \\
2.52 \\
1.68 \\
1.55 \\
2.73 \\
1.53 \\
0.95\end{array}$ & $\begin{array}{l}0.57 \\
0.45 \\
0.54 \\
0.76 \\
0.71 \\
0.52 \\
0.49 \\
0.65 \\
0.50 \\
0.43\end{array}$ & $\begin{array}{l}0.31 \\
0.27 \\
0.28 \\
0.38 \\
0.36 \\
0.31 \\
0.48 \\
0.36 \\
0.30 \\
0.26\end{array}$ & $\begin{array}{l}97.64 \\
97.04 \\
97.36 \\
98.48 \\
97.95 \\
97.35 \\
98.16 \\
98.31 \\
97.21 \\
96.60\end{array}$ & $\begin{array}{l}41.81 \\
42.33 \\
41.79 \\
40.69 \\
41.01 \\
42.08 \\
42.10 \\
41.34 \\
42.15 \\
42.84\end{array}$ \\
\hline $\begin{array}{l}80.90 \\
81.51 \\
79.38 \\
84.68\end{array}$ & $\begin{array}{r}12.57 \\
10.63 \\
9.67 \\
7.25\end{array}$ & $\begin{array}{l}2.53 \\
3.42 \\
5.40 \\
4.09\end{array}$ & $\begin{array}{l}0.57 \\
1.04 \\
1.87 \\
1.22\end{array}$ & $\begin{array}{l}0.33 \\
0.39 \\
0.56 \\
0.43\end{array}$ & $\begin{array}{l}0.17 \\
0.24 \\
0.31 \\
0.20\end{array}$ & $\begin{array}{l}97.06 \\
97.23 \\
97.19 \\
97.87\end{array}$ & $\begin{array}{l}43.44 \\
42.71 \\
41.47 \\
41.98\end{array}$ \\
\hline $\begin{array}{l}93.51 \\
92.93 \\
94.89 \\
94.20 \\
93.48 \\
94.62 \\
88.40 \\
91.90\end{array}$ & $\begin{array}{l}3.09 \\
3.06 \\
2.20 \\
2.66 \\
3.21 \\
2.46 \\
4.68 \\
3.61\end{array}$ & $\begin{array}{l}1.44 \\
1.81 \\
1.47 \\
1.58 \\
1.47 \\
1.15 \\
3.05 \\
1.84\end{array}$ & $\begin{array}{l}0.36 \\
0.38 \\
0.25 \\
0.36 \\
0.39 \\
0.26 \\
0.98 \\
0.48\end{array}$ & $\begin{array}{l}0.23 \\
0.22 \\
0.18 \\
0.21 \\
0.21 \\
0.17 \\
0.38 \\
0.24\end{array}$ & $\begin{array}{l}0.15 \\
0.13 \\
0.10 \\
0.11 \\
0.09 \\
0.10 \\
0.26 \\
0.14\end{array}$ & $\begin{array}{l}98.79 \\
98.52 \\
99.09 \\
99.11 \\
98.85 \\
98.76 \\
97.75 \\
98.21\end{array}$ & $\begin{array}{l}43.30 \\
43.13 \\
43.25 \\
43.17 \\
43.25 \\
43.18 \\
42.53 \\
43.13\end{array}$ \\
\hline $\begin{array}{l}89.84 \\
86.33 \\
94.49 \\
93.09 \\
93.48\end{array}$ & $\begin{array}{l}5.81 \\
7.31 \\
2.76 \\
2.96 \\
2.26\end{array}$ & $\begin{array}{l}1.53 \\
2.49 \\
0.81 \\
1.50 \\
2.51\end{array}$ & $\begin{array}{l}0.44 \\
0.61 \\
0.18 \\
0.24 \\
0.30\end{array}$ & $\begin{array}{l}0.23 \\
0.30 \\
0.16 \\
0.18 \\
0.21\end{array}$ & $\begin{array}{l}0.10 \\
0.15 \\
0.08 \\
0.12 \\
0.12\end{array}$ & $\begin{array}{l}97.94 \\
97.19 \\
98.48 \\
98.08 \\
98.88\end{array}$ & $\begin{array}{l}43.57 \\
43.36 \\
43.70 \\
43.14 \\
42.26\end{array}$ \\
\hline $\begin{array}{l}94.60 \\
93.75 \\
96.77 \\
96.22\end{array}$ & $\begin{array}{l}2.00 \\
2.58 \\
1.49 \\
1.67\end{array}$ & $\begin{array}{l}1.64 \\
1.34 \\
0.51 \\
0.70\end{array}$ & $\begin{array}{l}0.16 \\
0.40 \\
0.09 \\
0.10\end{array}$ & $\begin{array}{l}0.15 \\
0.26 \\
0.12 \\
0.14\end{array}$ & $\begin{array}{l}0.10 \\
0.16 \\
0.07 \\
0.11\end{array}$ & $\begin{array}{l}98.65 \\
98.48 \\
99.05 \\
98.94\end{array}$ & $\begin{array}{l}42.90 \\
43.10 \\
43.59 \\
43.50\end{array}$ \\
\hline
\end{tabular}


DESCRIPTION

\begin{tabular}{|c|c|c|c|}
\hline $\begin{array}{c}\text { Sample } \\
\text { Level } \\
\text { (feet) }\end{array}$ & $\begin{array}{c}\text { Ledge } \\
\text { No. }\end{array}$ & $\begin{array}{c}\text { Thickness } \\
\text { (feet) }\end{array}$ & Lithology \\
\hline $\begin{array}{l}30-31 \\
31-32 \\
32-33 \\
33-34 \\
34-35 \\
35-36 \\
36-37 \\
37-38 \\
38-39 \\
39-40\end{array}$ & 6 & 10 & $\begin{array}{l}\text { Dolomitic limestone, very pale-yellowish-brown to yellowish-brown (with } \\
\text { intricate medium-gray to medium-dark-gray mottling), very finely crystal- } \\
\text { line; irregular lenses and layers of very pale-yellowish-brown to dark-yel- } \\
\text { lowish-brown (with intricate medium-gray to medium-dark-gray mot- } \\
\text { tling), micrograined limestone, with few coarser bioclastic grains and fossil } \\
\text { fragments, partly with conchoidal fracture (dominant lithology in interval } \\
35-36 \text { feet); micrograined limestone locally mottled with small irregular } \\
\text { and circular bodies of very finely crystalline dolomite; in part very fine-to } \\
\text { coarse-grained, bioclastic, pelletal limestone in basal foot; sparsely fossilif- } \\
\text { erous (brachiopods, colonial corals, and bryozoans); slightly argillaceous; } \\
\text { stylolitic; massive to thick-bedded. }\end{array}$ \\
\hline $\begin{array}{l}40-41 \\
41-42 \\
42-43 \\
43-44\end{array}$ & 7 & 4 & $\begin{array}{l}\text { Limestone, pale-yellowish-brown to dark-yellowish-brown, and medium- } \\
\text { olive-gray, micrograined, with few coarser bioclastic grains, subconchoidal } \\
\text { fracture; mottled with small circular and irregular bodies of pale-yellowish- } \\
\text { brown to very dark-yellowish-brown, very finely crystalline dolomite; in } \\
\text { part very finely crystalline dolomite and dolomitic limestone, irregularly } \\
\text { interlayered with micrograined limestone; rarely fossiliferous (brachio- } \\
\text { pods); slightly argillaceous; few stylolites; thin- to medium-bedded. }\end{array}$ \\
\hline $\begin{array}{l}44-45 \\
45-46 \\
46-47 \\
47-48 \\
48-49 \\
49-50 \\
50-51 \\
51-52\end{array}$ & 8 & 8 & $\begin{array}{l}\text { Limestone, pale-yellowish-brown to dark-yellowish-brown, micrograined, } \\
\text { with coarser bioclastic grains and fossil fragments (gastropods), subcon- } \\
\text { choidal fracture; in part very fine- to very coarse-grained, intraclastic, bio- } \\
\text { clastic, pelletal limestone; mottled with small irregular bodies and thin } \\
\text { seams of very pale-yellowish-brown to dark-yellowish-brown, very finely } \\
\text { crystalline dolomite; stylolitic; medium- to thin-bedded. }\end{array}$ \\
\hline $\begin{array}{l}52-53 \\
53-54 \\
54-55 \\
55-56 \\
56-57\end{array}$ & 9 & 5 & $\begin{array}{l}\text { Limestone, pale-yellowish-brown to dark-yellowish-brown, micrograined, } \\
\text { with few coarser bioclastic grains and fossil fragments (brachiopods and } \\
\text { gastropods), subconchoidal fracture; in part very fine- to very coarse- } \\
\text { grained, intraclastic, bioclastic, pelletal limestone (siliceous matrix locally } \\
\text { in interval } 56-57 \text { feet); mottled with small irregular bodies of very pale-yel- } \\
\text { lowish-brown to dark-yellowish-brown, very finely crystalline dolomite; } \\
\text { prominent color-banded, wavy structure in interval } 56-57 \text { feet consisting of } \\
\text { light-colored bands of very finely to coarsely crystalline calcite (with local } \\
\text { laminae of micrograined limestone) separated by dark-colored band of fine- } \\
\text { to medium-grained limestone; thin seams and small bodies of white to very } \\
\text { light-gray, earthy, siliceous(?) material in intervals } 53-54 \text { and } 55-56 \text { feet; vug } \\
\text { filled with crystalline calcite in interval } 56-57 \text { feet; few stylolites; medium- } \\
\text { to thick-bedded. }\end{array}$ \\
\hline $\begin{array}{l}57-58 \\
58-59 \\
59-60 \\
60-61\end{array}$ & 10 & 4 & $\begin{array}{l}\text { Limestone, pale-yellowish-brown to very dark-yellowish-brown, very fine- } \\
\text { to very coarse-grained, pelletal, bioclastic, intraclastic; in part micrograined } \\
\text { limestone with coarser bioclastic grains and fossil fragments (bryozoans, } \\
\text { brachiopods, and colonial corals-Tetradium); small amount of mottling } \\
\text { with small irregular bodies of pale-yellowish-brown to very dark-yellow- } \\
\text { ish-brown, very finely crystalline dolomite; stylolitic; thick-bedded. }\end{array}$ \\
\hline
\end{tabular}


CHEMICAL ANALYSIS

\begin{tabular}{|c|c|c|c|c|c|c|c|}
\hline $\begin{array}{c}\% \\
\mathrm{CaCO}_{3}\end{array}$ & $\begin{array}{c}\% \\
\mathrm{MgCO}_{3}\end{array}$ & $\begin{array}{c}\% \\
\mathrm{SiO}_{2}\end{array}$ & $\begin{array}{c}\% \\
\mathrm{Al}_{2} \mathrm{O}_{3}\end{array}$ & $\begin{array}{c}\% \\
\mathrm{Fe}_{2} \mathrm{O}_{3}\end{array}$ & $\begin{array}{c}\% \\
\mathrm{SO}_{3}\end{array}$ & $\begin{array}{c}\% \\
\mathrm{TOTAL}\end{array}$ & $\begin{array}{c}\% \\
\text { LOI }\end{array}$ \\
\hline & & & & & & & \\
& & & & & & & \\
94.68 & 2.28 & 5.48 & 0.23 & 0.16 & 0.10 & 102.93 & 43.27 \\
94.27 & 1.83 & 1.41 & 2.00 & 0.19 & 0.14 & 99.84 & 43.00 \\
94.91 & 1.92 & 1.02 & 0.24 & 0.16 & 0.14 & 98.38 & 43.40 \\
87.95 & 6.59 & 1.99 & 0.48 & 0.24 & 0.13 & 97.39 & 43.28 \\
85.82 & 8.43 & 1.90 & 0.39 & 0.22 & 0.10 & 96.86 & 43.67 \\
85.16 & 8.61 & 1.68 & 0.40 & 0.21 & 0.05 & 96.11 & 43.70 \\
& & & & & & & \\
\end{tabular}


DESCRIPTION

\begin{tabular}{|c|c|c|c|}
\hline $\begin{array}{c}\text { Sample } \\
\text { Level } \\
\text { (feet) }\end{array}$ & $\begin{array}{c}\text { Ledge } \\
\text { No. }\end{array}$ & $\begin{array}{c}\text { Thickness } \\
\text { (feet) }\end{array}$ & Lithology \\
\hline $\begin{array}{l}61-62 \\
62-63 \\
63-64 \\
64-65 \\
65-66 \\
66-67\end{array}$ & 11 & 6 & $\begin{array}{l}\text { Limestone, very pale-yellowish-brown to pale-yellowish-brown (in part } \\
\text { with medium-gray to dark-gray mottling), and yellowish-brown to dark- } \\
\text { yellowish-brown, micrograined, with few coarser bioclastic grains and fos- } \\
\text { sil fragments (brachiopods and gastropods), subconchoidal fracture; small } \\
\text { amount of mottling with small irregular bodies and seams of pale-yellow- } \\
\text { ish-brown to very dark-yellowish-brown, very finely crystalline dolomite; } \\
\text { micrograined limestone in part irregularly interlayered with very finely } \\
\text { crystalline dolomite in interval } 64-65 \text { feet; few seams of fine- to very coarse- } \\
\text { grained pelletal limestone in lower } 2 \text { feet; traces of pyrite in intervals } 61-62 \\
\text { and } 63-66 \text { feet; very thin to thin, calcite-filled fractures in interval } 61-65 \text { feet; } \\
\text { small calcite-filled vugs in interval } 63-67 \text { feet; stylolitic; thick-bedded. }\end{array}$ \\
\hline & & & Lower mine floor; bottom of sampled interval. \\
\hline
\end{tabular}

